\title{
Conversations and correspondence with Burns on the ethics of transforming leadership
}

\author{
Joanne B. Ciulla* \\ Professor and Coston Family Chair in Leadership and Ethics, Jepson School of Leadership Studies, \\ University of Richmond, VA, USA
}

\section{INTRODUCTION}

As I stood in the Williamstown College cemetery listening to the short eulogies for James MacGregor Burns, I reflected on our conversations and letters about leadership over the years. Burns and I were the first two faculty hired by the Jepson School of Leadership Studies. If the university had not hired Burns first, I might not have ended up at Jepson. I arrived on campus in 1991 and with three other faculty members and the school's two deans we designed all aspects of the school from the admission policies to the curriculum. Burns was not involved in this process. His job as Senior Fellow was to visit periodically and discuss our research with us.

As a novice in leadership studies I immediately began reading the major books and articles in the field. When Burns visited the school, he would have lunch with each of the faculty members to discuss their work. These were truly great lunches. As my area of research is ethics, our conversations centered around two issues: Burns's account of ethics based on modal values and end values and the public and private morality of leaders. Over the next 22 years, Burns and I discussed and corresponded on these subjects. We agreed about many things in general but often saw the details quite differently. We never changed each other's minds but that did not deter either of us from continuing to argue about various aspects of ethics and leadership. In this article I will describe some of our discussions that took place in person and by mail.

\section{LANGUAGE PROBLEMS}

The first thing that struck me in the leadership literature was the overarching concern that leadership scholars had about the definition of leadership. This concern was particularly evident in Joseph Rost's book, Leadership for the Twenty-First Century (1991). As most of the literature consisted of empirical studies, which required simple definitions, this was understandable. However, the focus on finding a definition of leadership went beyond the practical considerations of doing social science studies. Some scholars seemed to believe that if we could only define leadership once and for all, we

\footnotetext{
* Joanne B. Ciulla one of the founders of the Jepson School of Leadership Studies, University of Richmond. She has also held academic appointments at La Salle University, Harvard Business School, The Wharton School, and held the UNESCO Chair in Leadership Studies at the UN University in Jordan. She has a BA, MA and PhD in philosophy and publishes extensively on leadership ethics, business ethics, and philosophy of work. Her most recent book is Ethics, The Heart of Leadership, 3rd edition (Praeger, 2014).
} 
would actually understand it. As a philosopher, this did not make sense to me. We can stipulate the definition of a leader for the purpose of a study or an argument, but the actual meaning of a word evolves through usage and experience, not because a scholar or group of scholars decide by caveat the meaning at a meeting or in a journal article or book. What leadership is for the scholar has to fit with the way ordinary people understand the term and the phenomenon. If it does not, then leadership scholars will find themselves talking to each other in their own private language.

As I saw it, the definition problem stemmed from the fact that the words 'leader' and 'leadership' carried quite a bit of normative baggage. When most people define the term 'leader,' they describe what a leader is and what a leader ought to be. The difference in definitions is a difference in what people think leaders should be. When I sent Burns the paper with this analysis of the definition problem (Ciulla 1995), he replied:

I was impressed by your relaxed and reasonable approach to defining leadership. Perhaps some day we will have become so successful in leadership theory we can then work out a satisfactory definition! ${ }^{1}$

This was vintage Burns, he had a charming way of stonewalling an idea. Burns then went on to talk about defining other terms:

I do think, though, that we can and should define specific terms more clearly. We (writers on leadership) variously use the terms ethics, values, moral dimensions, moral virtue, and endgoals, substantive values (justice, equality, etc.), and others. I tend to use the term 'end-values,' but it may not be quite right. But at least we should, I suggest, sharply discriminate in our definition (and concept) between norms of behavior or codes of conduct on the one hand, and the palpable, substantial collective goals of justice and the like, or equality, on the other. ${ }^{2}$

Again the problem of language emerged, mainly because of our different disciplinary approaches. As the subject matter of philosophic ethics consists of what these terms mean, philosophers rarely offer simple definitions of them. One problem in leadership studies is getting people from different disciplines to understand each other. In the preface to my collection Ethics, The Heart of Leadership (Ciulla 1998), Burns complained that the contributors to the book did not make a distinction between ethical and moral leadership. As I pointed out to him on several occasions, that seems to be a distinction without a difference. The two words tend to define each other or eventually collapse into each other. I also noted that almost every writer who makes this distinction defines the difference in a different way - often to suit what he or she wants to say.

\section{ETHICS AND TRANSFORMING AND TRANSFORMATIONAL LEADERSHIP}

Whereas Burns and I agreed on the centrality of ethics to leadership and the need to account for the ethics of the leadership process as well as the ethics of the ends of leadership, we continued to disagree about how to talk about it. The moral questions that drive Burns's theory of transforming leadership emerge from his work as a biographer and a historian. When biographers or historians study a leader, they struggle with how to judge or keep from judging their subject. If you analyse the numerous historical examples in

1. James MacGregor Burns, Letter to Joanne Ciulla, March 12, 1995.

2. Ibid. 
Burns's book Leadership (1978), you find two pressing moral issues shape his leadership theory. The first is the morality of means and ends (this also includes the moral use of power) and the second is the personal morality of a leader. His theory of transforming leadership attempts to characterize good leadership by accounting for both of these.

Burns's distinction between transforming and transactional leadership and modal and end-values offers a way to think about the question, 'What is a good leader?'. Transactional leadership rests on what Burns calls the ethics of means or modal values, which are things like responsibility, fairness, honesty, and promise keeping. His modal values are simply moral principles, some of which philosophers might identify as duties or virtues. Burns's modal values are about how the leader treats followers. They say a lot about the ethics of the leader. So, while transactional leadership is not as lofty as transforming leadership, it is still the meat and potatoes of leadership. Burns rightly emphasizes the fact that transactional leadership requires a set of moral agreements to work.

Burns tells us that transforming leaders and followers elevate each through various stages of morality and need. ${ }^{3} \mathrm{He}$ calls his criteria for judging the results of this process 'end-values.' These include liberty, justice, and equality. For Burns, both leaders and followers have moral agency in the leadership process. Scholars often overlook this aspect of Burns's theory in part because they confuse transforming leadership with the much larger and more dominant literature on transformational leadership. Bernard Bass's original theory of transformational leadership does not emphasize the influence of followers on leaders. His work focuses on the psychology of transformational and transactional leadership based on measurements of individualized consideration, intellectual stimulation, inspirational motivation, and idealized influence (see Bass 1985). His early theory of transformational leadership was 'value free,' but there remained the assumption that transformational leaders were good in the moral and practical sense of the word.

Burns and I were equally confused over why Bass's transforming leader would be ethical. In response to my criticisms concerning ethics of transformational leaders, Bass had modified his theory to account for ethical and unethical leaders, which he called transformational (ethical) and pseudo-transformational (unethical) leaders. Bass emphasized the superiority of transformational leadership over transactional leadership. This is somewhat ironic as Bass's studies were mostly in business settings where transactional leadership would, on a practical level, be just as important as transformational leadership. In 1998, Burns commented on this:

There is an implication in Bass that transformational leadership calls for a higher level of morality than transactional. Of course this is not a new thought for us but he develops it interestingly. Could one argue that the master transactional leader really does not need to worry so much about morality because he or she engages in dealing or brokerage where it is assumed that the participants are operating in terms of self-interest - that it is understood and accepted? Or as the transformational leader has to deal with followers on the basis of trust

3. One of the problems with using the values approach to ethics is that it requires a very complicated taxonomy of values. The word value is also problematic because it is encompasses so many different kinds of things. The values approach requires arguments for some sort of hierarchy of values that would serve to resolve conflicts of values. In order to make values something that people do rather than just have, Milton Rokeach $(1973$, p. 9) offers a very awkward discussion of the ought character of values: 'A person phenomenological experiences "oughtness" to be objectively required by society in somewhat the same way that he perceives an incomplete circle as objectively requiring closure.' 
and perhaps not even exchange - perhaps even the transformational leader is given more leeway on this basis. Well, as you see, I may just be adding to the confusion! ${ }^{4}$

Burns does indeed add to the confusion about his own work, since Burns says that transactional leaders need to operate with modal values, which would, even on his limited account of them, include trust.

\section{PHILOSOPHIC ETHICS AND BURNS}

In terms of his ethical theory, Burns appears to be a consequentialist, despite his acknowledgment that 'insufficient attention to means can corrupt the ends' (Burns 1978, p. 426). However, because Burns does not really offer a systematic theory of ethics, he is difficult to categorize. Consider, for example, his two answers to the Hitler problem. In the first part of his book Leadership (ibid., p. 3), he says quite simply that once Hitler gained power and crushed all opposition, he was no longer a leader. He was a tyrant. Burns says that Hitler would probably argue that he was a transforming leader who spoke for the true values of the German people and elevated them to a higher destiny. Later in the book, he offers three criteria for judging how Hitler would fare before 'the bar of history.' First, Hitler would be tested by modal values of honor and integrity or the extent to which he advanced or thwarted the standards of good conduct in mankind. Second, he would be judged by the end values of equality, freedom, and justice. Last, he would be judged on the impact that he had on the well-being of the people that he touched (ibid., p. 426). According to Burns, Hitler would fail all three tests. He does not consider Hitler a leader or a transforming leader, because of the means that he used, the ends that he achieved, and the moral impact of Hitler on his followers. ${ }^{5}$

By looking at leadership as a process and not a set of individual acts, Burns's theory of good leadership is difficult to pigeonhole. Not surprisingly, because he is a historian, his theory seems more useful as a tool for assessing leadership after the fact. Near the end of Leadership, Burns offers an anecdote about why President Johnson did not run again for president in 1968. Burns (1978, p. 424) tells us, 'Perhaps he did not comprehend that the people he had led - as a part of the impact of his leadership - have created their own fresh leadership, which was now outrunning his.' All of the people who Johnson helped - the sick, the blacks, and the poor - now had their own leaders. Burns (ibid.) says, 'Leadership begat leadership and hardly recognized its offspring.' In his view of transforming leadership there is a kind of 'withering away' of the leader as followers become leaders. Apparently Johnson did not know that he was transforming people while he was doing it, which raises the question of whether you have to know you are a transforming leader to be one. Nonetheless, Johnson's leadership on civil rights fares well when measured against Burns's end values of liberty, justice, and equality.

Burns's theory of transforming leadership implies a dynamic relationship between leaders and followers. Nonetheless, his dependency on the idea of values offers a

4. James MacGregor Burns, Letter to Joanne Ciulla, June 12, 1998.

5. The third test has an Aristotelian twist to it. The relationship of leaders and followers and the ends of that relationship must rest on eudaimonia or happiness that is understood as human flourishing, or as Aristotle says, 'living well and faring well with being happy' (Aristotle, Nichomachean Ethics, Book I (1095a19) (trans. W.D. Ross) in The Complete Works of Aristotle, Vol. II, edited by Jonathan Barnes, Princeton, NJ: Princeton University Press, 1984, p. 1730). 
somewhat static picture of morality that fails to account for the varieties of moral agency. Burns refers to values as 'priorities' and 'standards' (ibid., p. 9). Ordinary moral language is much richer than the language of values. Burns tries to get values to do the work of other moral terms. He describes his terms in the following ways (ibid., p. 6):

Ethical Values: traditional 'character tests' such as chastity, sobriety,

abstention, kindness to the poor and ten commandment-type rules

Modal Values: honesty, trustworthiness, reliability, reciprocity and accountability

End Values: order, liberty, equality, justice, community

If we look at these values, we see Burns refer to virtues or habits of character along with some moral principles and then a specific application of a virtue such as kindness to the poor. Virtues tell us what we should be like and moral principles tell us what we should do. Values describe the overarching picture of what is important, but they are too general and inert to use to describe what actually goes on between people in the process of transforming leadership. Burns later relented and began to use virtues in the way that most philosophers understand the term. When he was researching his book on the Enlightenment, Fire and Light (Burns 2013), he wrote:

I won't respond substantively to you at this point, because I am somewhat distracted into other activities, but I do want to say, as I work on leadership during the Enlightenment, that I constantly see some validity in my approach to moral leadership as embracing virtues, ethics, and values. Working on Washington recently has been quite an eye opener, incidentally, in regards to virtues - as you doubtless know, he copied out a huge long list of behavioral virtues mainly designed to make him look as presentable as possible to his fellow planters, of course you and I are working on a higher level than that! ${ }^{6}$

I once asked Burns why he did not include happiness as an end value along with justice, liberty, equality. I pointed out that justice is an end in itself, but I am not sure that liberty and equality are ends in themselves. In a letter, I suggested that maybe Burns should include the Aristotelian notion of happiness (eudaimonia) as an end value because it is good in itself. Eudaimonia means happiness in the sense of human flourishing or well-being, which seemed to fit with what Burns wanted to say about well-being. Burns replied:

I would not mention this sickly sentimental term except for Jefferson, and before him

Furguson, et al in the Scottish Enlightenment, used it - and they really meant it, but we are not sure what they meant by it. Fulfillment, is it personal or collective? ${ }^{7}$

He then went on to say that he was going to see Rollo May that weekend and would ask him about it.

\section{BURNS'S CONTRIBUTION}

Despite my philosophic quibbling with Burns about ethics, I think the main reason why his work is so important to leadership studies and leadership ethics rests on the fact that he examined leadership through the lens of democracy, not management.

6. James MacGregor Burns, Letter to Joanne Ciulla, February 3, 2003.

7. James MacGregor Burns, Letter to Joanne Ciulla, April 13, 1994. 
In 2002, his editor at Grove Press asked me to review the manuscript for his book Transforming Leadership (2007). I particularly liked the wide variety of historical case studies about leaders in it. The only thing I found lacking was that it did not include a case about a business leader. I asked Burns why. He told me that he had an uncle who worked on Wall Street and when the stock market crashed in 1929, his uncle lost everything and committed suicide. Burns said, after that, he had never had any interest in business. I think one reason Burns did not engage the leadership studies literature in his writing is because so much of it is about management. Most businesses are not democracies, hence the assumptions about leaders and followers are different - that is, leaders are managers and followers are employees. This is why transformational leadership is about what leaders do to followers, whereas transforming leadership is what leaders and followers do to each other.

I think that leadership scholars, especially the ones in business schools, should re-examine Burns's work in light of their own. It would be interesting to consider what business organizations would be like if they used democratic values such as justice, equality, and liberty to measure the quality of their leaders and leadership. I am not suggesting that businesses become democracies but rather approach leadership as if they were. In many parts of the world today we see growing inequality in society and organizations. Some CEOs earn hundreds of times more than the lowest paid worker in their organizations. In the current precarious economic environment fear of unemployment sometimes restricts people's liberty to leave a job or express themselves on the job. All of this raises questions about how the actions of leaders in business and government measure up against democratic values such as equality, liberty, and justice. When we look at leadership as Burns did, through the values of democracy, we cannot avoid reflecting on the ethics of leaders and followers because both have the ability and the responsibility to transform each other, their organizations, and society.

\section{REFERENCES}

Bass, Bernard (1985), Leadership and Performance Beyond Expectations, New York: Free Press. Burns, James MacGregor (1978), Leadership, New York: Harper Torchbooks.

Burns, James MacGregor (2007), Transforming Leadership, New York: Grove Press.

Burns, James MacGregor (2013), Fire and Light: How the Enlightenment Transformed Our Lives, New York: Macmillan.

Ciulla, Joanne B. (1995), 'Leadership Ethics Mapping the Territory,' The Business Ethics Quarterly, 5(1), 5-28.

Ciulla, Joanne B. (1998), Ethics, The Heart of Leadership, Westport, CT: Quorum Books. Rokeach, Milton (1973), The Nature of Human Values, New York: Free Press. Rost, Joseph (1991), Leadership for the Twenty-First Century, New York: Praeger. 